\title{
Retraction Note: Drying of a plasmid containing formulation: chitosan as a protecting agent
}

\author{
Nasir Mohajel ${ }^{1,2}$, Abdolhossein R. Najafabadi ${ }^{1}$, Kayhan Azadmanesh ${ }^{3}$, Alireza Vatanara ${ }^{1}$, Mohsen Amini ${ }^{4}$,
} Esmail Moazeni ${ }^{1}$, Amirabbas Rahimi ${ }^{5}$ and Kambiz Gilani ${ }^{1 *}$

This article [1] has been retracted by the publisher because it was republished in the journal [2] due to an error during the process of journal transfer between publishers. BioMed Central apologizes to the authors and to readers for this error and for any inconvenience caused.

\footnotetext{
Author details

${ }^{1}$ Aerosol Research Laboratory, Department of Pharmaceutics, School of Pharmacy, Tehran University of Medical Sciences, Tehran, Iran. ${ }^{2}$ Department of Pharmaceutics, Faculty of Pharmacy, Shahid Sadoughi University of Medical Sciences, Yazd, Iran. ${ }^{3}$ Department of Virology, Pasteur Institute of Iran, Tehran, Iran. ${ }^{4}$ Department of Medicinal Chemistry, School of Pharmacy, Tehran University of Medical Science, Tehran, Iran. ${ }^{5}$ Department of

Nanobiotechnology, Pasteur Institute of Iran, Tehran, Iran.

Received: 16 March 2016 Accepted: 16 March 2016

Published online: 27 April 2016

\section{Reference}

1. Mohajel N, Najafabadi AR, Azadmanesh K, Vatanara A, Amini M, Moazeni E, Rahimi A, Gilani K: Drying of a plasmid containing formulation: chitosan as a protecting agent. DARU J Pharm Sci. 2012;20:29.

2. Mohajel N, Najafabadi AR, Azadmanesh K, Amini M, Vatanara A, Moazeni E, Rahimi A, Gilani K: Drying of a plasmid containing formulation: chitosan as a protecting agent. DARU J Pharm Sci. 2012;20:22.
}

\footnotetext{
* Correspondence: gilani@sina.tums.ac.ir

The online version of the original article can be found under doi:10.1186/2008-2231-20-29.

${ }^{1}$ Aerosol Research Laboratory, Department of Pharmaceutics, School of

Pharmacy, Tehran University of Medical Sciences, Tehran, Iran
}

Submit your next manuscript to BioMed Central and we will help you at every step:

- We accept pre-submission inquiries

- Our selector tool helps you to find the most relevant journal

- We provide round the clock customer support

- Convenient online submission

- Thorough peer review

- Inclusion in PubMed and all major indexing services

- Maximum visibility for your research

Submit your manuscript at

www.biomedcentral.com/submit 